Sławomir Sobieraj

ORCID: 0000-0001-6332-692X

Uniwersytet Przyrodniczo-Humanistyczny w Siedlcach Wydział Nauk Humanistycznych

\title{
Topos lasu w poezji Bolesława Leśmiana. Natura - człowiek - Bóg
}

\author{
https://doi.org/10.34739/clit.2021.15.12
}

\section{Topos of the Forest in Bolesław Leśmian's Poetry. Nature - Human - God}

\begin{abstract}
The article presents interpretations of poems by Bolesław Leśmian, where a motif of the forest can be found. Initially, the forest in Leśmian's poetry appears as symbolism of spiritual states: melancholy, longing and sadness, which are the characteristic features of the Young Poland poetry, which was primarily patronized by Kazimierz Przerwa-Tetmajer. Then, in the poems from Orchard, he announces the project of a union of human and nature and a turn towards the original instinctuality, the implementation of which the next volume will bring.

Aa essential text is the poem Green Hour. This is the mystery of the existential tragedy of the human who lives on the border between the worlds: nature, human civilization and God. Here we can see the unveiling of the idea of realistic symbolism, which involves the search for mediation between different entities. However, he does not come to it because of the fact that the protagonist of the described events is under the influence of principio individuationis. Only the resignation from this principle - which occurs in the poems of Oak and Desire, and in other works of The Meadow - shows the space of the forest as a place of reconciliation between beings. In the interpretation, it was noticed that Leśmian's cosmogonic concepts were inspired by the philosophical thought of Friedrich Nietzsche and Henri Bergson.
\end{abstract}

Keywords: forest, nature, man, symbolism, God, Bolesław Leśmian

Natura, żywioł przedstawiany przez Bolesława Leśmiana w ujęciu kosmologicznym, przybiera jego w wierszach rozmaite oblicza. Najbardziej znane są te, które poeta zarysował w symbolicznych określeniach, zawartych w tytułach swoich książek lirycznych: sad i łąka. Nieco zakamuflowane zostało odmienne nazwanie natury jako lasu w tytule pośmiertnego tomu utworów - Dziejba leśna (1938). Natomiast w wywiadzie, którego udzielił 
twórca w końcu lat trzydziestych 20. wieku, użył jeszcze innego określenia: zieloność1. Pochodziło ono z tomu Łąka (sformułowanie „Niepojętość Zieloności" pojawia się w tytułowym poemacie). Na symboliczny charakter owych nazw natury, stosowanych przez Leśmiana zamiennie, wskazuje chociażby początek wiersza Topielec, w którym znajdujemy niejednoznaczną i trochę przewrotną lokalizację wydarzeń:

W zwiewnych nurtach kostrzewy, na leśnej polanie, Gdzie się las upodabnia lące niespodzianie².

W utworze tym las staje się łąką i na powrót borem, a bohater tytułowy jest „topielcem zieleni”, „zieleni samej w sobie”, której bezkresy zwiedza i wśród której ginie, „odczłowieczając duszę”, by stać się paradoksalnie martwym „w stu wiosen bezdeni”3. Zieleń i zieloność zatem to kolejne synonimy interesującego nas pojęcia. Notabene, także tytuł ostatniego wydanego za życia poety zbioru poetyckiego (Napój cienisty) nawiązuje aluzyjnie do motywiki lasu, o czym zdaje się przekonywać epitet użyty w cytowanym wyżej wierszu: „cienisty jak bór w borze”.

Mając na uwadze ewolucję liryki Leśmiana i jego poglądów na sztukę4, podejmę się próby ukazania różnych przedstawień lasu, które występują w wierszach poety, w ujęciu historycznoliterackim. Uwzględniam zatem chronologię ich powstawania, konteksty biograficzne i wypowiedzi o charakterze publicystycznym, dające wyraz świadomości artystycznej twórcy. Pragnąc uniknąć jednostronności interpretacyjnej, która mogłaby zacierać autonomiczne znaczenia utworów autora Napoju cienistego, reprezentatywne dla „leśnej” tematyki, widzę podobieństwo idei i technik poetyckich wierszy z różnych okresów jego twórczości, ale też dostrzegam różnice. Daleki jestem od poszukiwania formuł uniwersalnych na siłę.

Pisząc o toposie lasu u Leśmiana, nie sposób pominąć tego, że już jako początkujący twórca wprowadził on do swojego pseudonimu literackiego morfem leksykalny w postaci alternantu „leś”, który oznaczał zwarty zespół roślinności z przewagą drzew. Przeróbka rodowego nazwiska

\footnotetext{
${ }^{1}$ W niepojętej zieloności. Rozmowa z Bolestawem Leśmianem, „Pion” 1937, nr 23.

2 B. Leśmian, Poezje zebrane, oprac. J. Trznadel, Warszawa 2010, s. 137. Wszystkie przywoływane wiersze poety, cytowane z tego wydania oznaczam skrótem PZ.

3 Ibidem.

4 Na niejednorodność poezji Leśmiana i metamorfozy jego światopoglądu artystycznego zwrócił szczególną uwagę Piotr Łopuszański, zob. idem, „Idący z prawdą u warg i u powiek...”. Próba nowego spojrzenia na twórczość Bolesława Leśmiana, „Teksty Drugie” 2002, nr 6, s. 181.
} 
dawała bardzo poetycki efekt dzięki zamianie obydwu cząstek: „les” i „man” na polskobrzmiące. Objaśniał tę przemianę Mieczysław Jachimowicz, pisząc o autorze Napoju cienistego:

Nawet nazwisko sobie przeinaczył na miarę swojej poezji. Arcyspolszczył. I u-Leśmianił. Urobił z żywiołu, z którym się utożsamiał: z zieleni i słowa. Lasu i miana. Aby uimiennić to, co szło od przyrody i nigdy nie będzie mogło jej opuścić5.

Być może, Leśne Miano w nazwisku miało wpływ na stosunkowo niską frekwencję słowa las w liryce autora Przygód Sindbada Żeglarza. Nie zmienia to faktu, że właśnie las w jego twórczości jest kojarzony z tym, co mu najbliższe i najbardziej drogocenne.

Wśród młodopolskich wierszy, obrazujących w sposób impresjonistyczny pejzaże duszy, wielokrotnie pojawiają się obrazy natury jako lasu. Las oprócz wielorakich konotacji symbolicznych naddanych przez poetów, uzyskiwał jednakże bardzo często status dekoracji, tła, na które „ja” liryczne projektowało swoje marzenia i uczucia ${ }^{6}$. Podobnie w młodzieńczych utworach Leśmiana, jak np. Sonet (inc. Pieśniowa słodycz lasu się wylewa ...), opublikowany w krakowskim „Życiu” w 1898 roku i Las (pierwodruk w warszawskim „Głosie” z 1901 r.), mamy do czynienia z poezją opisowonastrojową, w której analogie między światem przyrody a osobą mówiąca składały się na typowy dla literatury tej epoki sposób wyrażania stanów duchowych. Znać w tych i innych wczesnych wierszach Leśmiana wpływy Kazimierza Przerwy-Tetmajera i Antoniego Langego. Nie tylko w zakresie poetyki impresjonizmu i symbolizmu, ale również w wymiarze ideowym, gdy powiela lub przetwarza klisze dekadenckich melancholii, smutków i zwątpień. Chociaż należy dodać, że ślady tych ostatnich można odnaleźć w zaledwie kilku tekstach (jak np.: Nadaremność, Jesienią, Sonet II).

Najprawdopodobniej autor, redagując książkowy debiut poetycki, dostrzegł schematyczność wspomnianych wypowiedzi i postanowił zrezygnować z ich ponownego wykorzystania. Tym bardziej, że właśnie w tym czasie formułował swój oryginalny program poezjī, co poświadczają listy i eseje. Ostatecznie pełni niepowtarzalnego stylu artystycznego

\footnotetext{
5 M. Jachimowicz, Bolesna stawa Leśnego Miana, „Poezja” 1967, nr 12, s. 71.

${ }^{6}$ A. Rossa, Impresjonistyczny świat wyobraźni. Poetycka i malarska kreacja pejzażu. Studium wybranych motywów, Kraków 2003, s. 251.

7 Por. P. Łopuszański, „Idacy z prawdą...”, op. cit., s. 190.
} 
dopracował się dziesięć lat później w Łące, tomie w jego dorobku cenionym najwyżej przez krytyków dwudziestolecia międzywojennego.

Nieco inny charakter, mniej młodopolski, nosi późniejszy wiersz z roku 1910, również opatrzony tytułem Las, który został umieszczony w cyklu Pieśni mimowolnych w zbiorze Sad rozstajny. Oczywiście także ten tekst należy odczytywać symbolicznie. Mimo że poeta już wówczas odżegnywał się od symbolizmu graniczącego z alegoryzmem, wciąż posługiwał się językiem szyfrującym znaczenia, odsyłającym do tego, co niewyrażalne i związane z doświadczaniem niezwykłych doznań. Przed laty Artur Sandauer zauważał, że Leśmian w tej fazie swojej twórczości przedstawiał „nie konkretność, lecz ideową esencję zjawisk”. Da się to pogodzić z sądami współczesnego badacza, Edwarda Bonieckiego, który pisząc o ewolucji metody twórczej Leśmiana twierdzi, że dopiero w Eace przybrała ona w pełni postać symbolizmu realistycznego, a wcześniej a więc także w Sadzie rozstajnym - był to jedynie symbolizm idealistyczny 9 , inspirowany poezją francuską. Niewątpliwie jest w tych zapatrywaniach sporo racji, jednakże należy pamiętać, że debiutancki tom Leśmiana był zbiorem niejednolitym ${ }^{10}$, zbierającym teksty powstałe $\mathrm{w}$ długim okresie czasu. Stąd też obecność w nim wierszy, które zapowiadają upodobanie w konkrecie i realności, czego przykładem jest poemat Zielona godzina, interpretowany w dalszej części szkicu.

Powróćmy do wspomnianego utworu z Pieśni mimowolnych. Mowa tu o myślach snutych w szczególnym momencie, tj. w chwili śmierci. Osoba liryczna zadaje pytania o nie, podając w wątpliwość kolejne odpowiedzi, opatrzone znakiem zapytania. Tym samym podkreśla ich tryb przypuszczający, możliwy, a niepewny. Dopiero finał utworu przynosi konkluzję oznajmującą, która waloryzuje las, przedstawiając go jako serdecznego przyjaciela:

\footnotetext{
8 Zob. A. Sandauer, Pośmiertny tryumf Młodej Polski (Rzecz o Bolestawie Leśmianie), [w:] idem, Poeci trzech pokoleń, wyd. IV, Warszawa 1973, s. 35. Krytyk trafnie zauważa, że Sad rozstajny w przeważającej mierze „ma jeszcze charakter symboliczny”, choć wskazuje na wyjątki od tej reguty.

9 E. Boniecki, Archaiczny świat Bolestawa Leśmiana. Studium historycznoliterackie, Gdańsk 2008, s. 33. Rozróżnienie między symbolizmem idealistycznym a realistycznym wyprowadza badacz na kanwie przemyśleń Wiaczesława Iwanowa, pierwszemu przypisując traktowanie symbolu jako umownego znaku, który mediuje między indywidualnościami, w drugim natomiast widząc „wspólny wgląd mistyczny” i przekraczanie prymatu indywidualności. Tak postrzegany symbolizm realistyczny przeradza się w mitotwórstwo, a sam symbol staje się zalążkiem mitu. Zob. ibidem, s. 28-29.

$10 \mathrm{Na}$ heterogeniczność tomu zwracał również uwagę wspomniany wyżej badacz, zob.

E. Boniecki, Archaiczny..., op. cit., s. 10.
} 
Pomyśl, gdy będziesz konał - czym się w tej godzinie

Twoja pamięć obarczy, nim szczeźnie a minie,

Wszystką ziemię ostatnim całująca tchem?

Czy wspomnisz dzień młodości - najdalszy od ciebie -

Za tę jego najdalszość, za odlot w podniebie,

Za to, że w noc konania nie przestał być dniem?

Czy wspomnisz czyjeś twarze, co - wspomniane - zbledną?

(...)

Lub ci może zielonym narzuci się złotem

Las, widziany przygodnie - niegdyśs - mimolotem,

Co go wywiódł z pamięci nieprzytomny czas?...

I ócz zezem niecałe rojąc nieboskłony,

Łzami druha powitasz i umrzesz, wpatrzony

W las nagły, niespodziany, zapomniany las!....1 ${ }^{11}$

Czymże jest las w tym wierszu? Jest czymś, co nie zostało w pełni dostrzeżone i docenione. Przygodnym i zapomnianym na długie lata. Na całe życie. Jest przy tym owiane tajemnicą. Może - paradoksalnie - jest właśnie ludzkim życiem? Jego głębszą istotą? Naturą samą w sobie? Bogiem? Szukając odpowiedzi na te pytania, można próbować odszyfrowania znaczeń symbolicznych kolorów: złota i zieleni. Złoto wskazuje na przestrzeń sakralną, wieczność, szlachetność i niezniszczalnośćc ${ }^{12}$. Zieleń natomiast to symbol przyrody i życia (także odrodzonego), nieśmiertelności i wolności ${ }^{13}$. „Nieprzytomny czas” - czas mierzony działaniami i aktywnością człowieka - „wywiał z pamięci” przyrodę, z którą w obliczu zgonu bohater czuje się serdecznie związany. Ma ona też w sobie cechy swoistej boskości, ale las w tym wypadku występuje obok nieba jako byt osobny.

Refleksja eschatologiczna, którą wprowadza do utworu wykorzystanie figury wyobrażeniowej lasu, wskazuje na ważny w liryce Leśmiana archetyp wegetacyjny ${ }^{14}$. O wiele bardziej jest on uobecniony w poemacie Zielona godzina, gdzie nawet Bóg został wpisany w Wielki Proces Wegetacji:

Spadły z nieba bezwolnie wraz z poranną rosą -

Drzemie Bóg, w macierzankach poległy na wznak ( $\mathrm{PZ} 36)$.

\footnotetext{
${ }^{11}$ B. Leśmian, Las, PZ, s.23.

12 Por. W. Kopaliński, Stownik symboli, Warszawa 2001, s. 502.

13 Ibidem, s. 498-499.

14 Omawia jego znaczenie na przykładzie wybranych wierszy jedna z badaczek Leśmiana, zob. M. Karwowska, Watki antropologiczne w «Sadzie rozstajnym» Bolestawa Leśmiana, [w:] Stulecie «Sadu rozstajnego», red. U.M. Pilch, M. Stala, Kraków 2014, s. 327-328, 333.
} 
$\mathrm{Z}$ jednej strony można mówić $\mathrm{w}$ tym wypadku o symbolice macierzanki, ziela znanego pod nazwą „macierza duszka”, która przez jedną z badaczek jest interpretowana jako określenie Wielkiej Macierzy i nieśmiertelności, z drugiej natomiast strony nasuwa się myśl o podobieństwie tego przedstawienia do znanego z kultów chtonicznych oraz poezji barokowej motywu grobu kolebki i śmierci traktowanej jako powrót do domu. Przecież sam las w wyobrażeniach ludzi kultur pierwotnych był jednym ze znaków tellurycznych, ale też miejscem świętym i pierwszym domem człowieka'15.

$\mathrm{Z}$ punktu widzenia projektu artystycznego najważniejszym ogniwem w Sadzie rozstajnym, bardzo bogatym w semantykę związaną z lasem, jest składający się z dziesięciu części poemat Zielona godzina. Poeta przywiązywał do tego tekstu dużą wagę, rozważał nawet opatrzenie jego tytułem pierwszego tomu poezji, co mu wyperswadował Przesmycki. Istotnie, Zielona godzina ze względu na wielowątkową treść i pokaźny rozmiar, stanowi wypowiedź znaczącą dla zrozumienia programu literackiego jej autora. To swoisty traktat o tragizmie ludzkiej kondycji rozpostartej między własnym ja, Bogiem i naturą.

Natura jest dla człowieka istotnym punktem odniesienia: on stanowi jej część, a ona jest w nim. To nowy sposób pisania o przyrodzie, odchodzący od modelu młodopolskich pejzaży wewnętrznych, a wiodący $\mathrm{w}$ stronę koegzystencji i zbliżenia ${ }^{16}$. Natura jest tym, z czego wywodzi się człowiek, skąd wyrusza w świat podniebny i nadziemny. Ale nigdy do końca nie traci $\mathrm{z}$ nią kontaktu. Nie jest też możliwe zupełne $\mathrm{z}$ nią zjednoczenie i identyfikacja. Tu tkwi przyczyna tragizmu.

Poemat rozpoczyna apostrofa do lasu, jego wezwanie. „Wód prądy i drzewa" cieszą się z powrotu zabłąkanego wędrowca, dostrzegając w tym ingerencję Boga. Bohater liryczny ma odczucie widzącej przyrody, ze zdziwieniem konstatuje utratę atrybutów swojej jednostkowości: „Jeszcze moja przed chwilą - już niczyja twarz...” (PZ 31). Jednak ostatecznie stwierdza, że odbywa się to zgodnie z jego intencją: „Wszak mówiłem: gdy przyjdzie Godzina Zielona - /Oddam lasom - co leśne, choćbym zginął sam!...” (PZ 31). Idea zanurzenia się w naturze, wiążąca się z utratą tożsamości, tutaj nie zostanie spełniona. Podjęta raz jeszcze we wzmiankowanym już Topielcu i w kolejnych wierszach Łąki, dopiero tam znajdzie właściwe rozwinięcie.

\footnotetext{
${ }_{15}$ Zob. W. Kopaliński, Stownik..., op. cit., s. 186-187.

${ }^{16}$ Por. M. Podraza-Kwiatkowska, Z rozważań nad tytutem „Sad rozstajny”, [w:] Stulecie «Sadu rozstajnego», red. U. Pilch, M. Stala, Kraków 2014, s. 12.
} 
W następnych dwóch sekwencjach poematu, pełnych ekstatycznych uniesień, znajdujemy opis wejścia w głąb lasu, nadejścia „zielonej godziny”. Oznacza ona czas życia w przyrodzie samej. Las zespolony z tą godziną zdaje się dawać podmiotowi wiersza obietnicę bezpiecznego schronienia, znalezienie prawdziwego domu. Jest to jednak, jak się później okaże, jedynie pozór spełnionej unii człowieka i natury. Zresztą, już tu możemy odnaleźć cechę szczególną wędrowca powracającego z obcego terytorium - „z gwiazd bezleśnych”, który mówi o sobie: „nie znam granic ni kresów!” (PZ 33), co może wskazywać na jego brak wierności swoim korzeniom. Być może, jest rozdarty między różnymi światami i w tym tkwi przyczyna jego tragizmu. Oddając się lasowi (naturze), w pewnym sensie wyrzeka się czysto ludzkiej bliskości i miłości. Do dziewczyny, domniemanej kochanki zwraca się podkreślając swoje poniekąd zdystansowanie: „Zawsze będę cię widział cudownie daleką - / Przez ukryty w mych oczach, nie znany ci las!”(PZ 34). Z kolei całkowita asymilacja z lasem nie jest możliwa, bo tylko, jak mówi, ciało jest na brzegu, „reszta w mroku den” (PZ 35). Reszta - czyli dusza. Potwierdza to usytuowanie pośrednie człowieka między przyrodą, Bogiem i własnymi ambicjami fragment: „Jam jest miejsce spotkania łez ze złotym kurzem/ Słońca, ptakom widnego!... Oto bór śni o mnie/ Sen, liśćmi zaprószony sen!”(PZ 35). Język symboliczny najlepiej charakteryzuje bohatera opisywanych zdarzeń, tj. „dźwigacza marzeń”, który nie przynależy w pełni ani do ziemi, ani do nieba. Jest odmieńcem. O tym mówi on również mową symboli:
A brzozy z trwogą na mnie patrzą z swej ustroni, Bo wiedzą, że mnie w ziemi pogrzebać nie wolno, Żem inny, niepodobny - odmieniec i dziw! (PZ 35).

Chwilowe zgoła spełnienie znajduje bohater w epifanijnej części szóstej poematu. Bóg i człowiek $\mathrm{w}$ obliczu przyrody transcendują ku sobie, przekraczając granice własnych bytów i wyobrażeń:

Pójdziem razem! Ramieniem własnym cię wspomogę!

Pokażę ci sny nasze i nasze moczary -

I słońce w oczach ptaków zapatrzonych w sad!...

Tak doń mówię - i z dłonią wyciągniętą mężnie

Nad nim, jak nad zwaloną od uderzeń bramą,

Trafiam na jego ku mnie wyciągniętą dłoń! 
I zgaduję - oczyma wodząc widnokrężnie -

Że on do mnie z parowu modlił się tak samo,

Jak i ja - nad parowem - modliłem się doń!... (PZ 36)

Zasadnicza różnica między wierszem Leśmiana a przekazami biblijnymi zasadza się w tym, że to człowiek staje się mediatorem między Bytem Najwyższym a Naturą, w której jest sam zapośredniczony. Bóg - „spadły z nieba bezwolnie" - nie jest wyniesiony ponad inne byty, traci swój wymiar Głównego Arbitra i wyłącznego sprawcy ziemskich zdarzeń. W tej potrójnej unii jest zrównany z pozostałymi jej uczestnikami. Również kreacja inicjatora procesu pojednania, opisywanego w cytowanym fragmencie, może skłaniać do sądu, że to człowiek dokonuje równania wspomnianych bytów.

Następujące potem ekstatyczne opisy natury przedstawiają obrazy widziane w sennym marzeniu. Dzwony Zielonej Godziny, przypominające transcendentalny nastrój wiersza Kazimierza Przerwy-Tetmajera $\mathrm{Na} \mathrm{Aniot}$ Pański, wprowadzają stan nadzwyczajny: słonecznego uniesienia, uświęcania duszy, jej identyfikacji z kwiatami i drzewami. Jednak jednanie człowieka z lasem jest obarczone znakiem zakłócenia: cieniem przyszłej „niewiadomej chaty”, która powstanie ze zniszczonego pnia dębu i „cieniem Boga”, który rzuca postać bohatera. Długo wyczekiwane spotkanie kończy rozdzieleniem pod wpływem „pierwszego lęku”, bohater utworu nagle stwierdza: „Cofnęliśmy się - każde w swą ciemność, w swój świat”. Jednakże w ostatniej części poematu, mimo świadomości obecności cienia, podejmuje on ponownie wyzwanie łączenia bytów: przyrody, Boga i człowieka.

Analizowany utwór odsłania zalążki rodzącej się wówczas egzystencjalnej filozofii Leśmiana, która ma rodowód epicko-tragiczny. Oscylacja na granicy trzech bytów: między przyrodą, Bogiem i własną niezależnością jest naznaczona tragizmem. Bierze się on z obowiązującej wciąż zasady prymatu indywidualności. Realizacja ludzkich pragnień i ambicji, związana z potrzebą rozwoju - jest przekroczeniem natury. Chata, która powstaje w wyniku „burzenia” drzewa żywego, symbolizuje tutaj konflikt bytów, naturalnego z cywilizowanym. Podobnie rzecz się ma z przekraczaniem człowieczeństwa w kierunku bogoczłowieczeństwa czego oznaką jest drugi cień. W Zielonej godzinie opisana została zatem 
egzystencja rozdarta ${ }^{17}$. Przezwyciężenie owego rozdarcia odnajdujemy dopiero w Łące, kiedy wieczna zieleń wkracza do chaty bohatera w sposób niekonfliktowy, przyczyniając się do jej przeobrażenia w byt naturalny („Na ścianach moich - rosa, na podłodze - kwiaty...”, PZ 291). Miłość, ogarniająca nie tylko przyrodę i indywiduum, ale też lud, w obecności Boga, daje podstawę do śpiewnego i tanecznego pląsu: ludzkich „rozwidnien” i rozweseleń.

Właśnie w Łące natrafiamy na kolejne dwa utwory zawierające semantykę lasu, już wyzbyte symboliki cienia, zagrażającego harmonijnej koegzystencji bytów. Należy do nich skomplikowana znaczeniowo ballada Dąb. Dochodzi w niej do unii ducha lasu z Bogiem w wyniku niesamowitej gry na kościelnych organach „upiora dębowego”, który „wygrzmiał z miechów to wszystko, co las myśli o Bogu!” (PZ 191).

Istota Najwyższa obdarzona została tutaj ludzkimi cechami i emocjami: przeżywa zachwyt i wzruszenie, można powiedzieć, że brata się z dębem-grajkiem-lasem. Wówczas - jak opowiada narrator - „znikła inszość i przedział” między nimi. Tak jakby przenikali się wzajemnie - łączyli w symbiotycznych działaniach. Tym samym las nabiera cech boskich, a Bóg leśnych.

Zgodnie z wyobrażeniami ludowymi, typowymi dla społeczeństw animistycznych - natura i Bóg to niezależne siły, tutaj ma miejsce ich nadzwyczajne pojednanie o randze cudu:

I Bóg słuchał wzruszony, słuchał duszą bezkreśną,

A w tej duszy mu było ruczajno i leśno,

I coś jeszcze miarkował i coś dumał na stronie

I biegł żywcem do grajka i wyciągał swe dłonie!

Święci, wiedząc, co czynią, w nagłej cudom podzięce

Poklękali radośnie, wziąwszy siebie za ręce,

Bo od kiedy świat światem, a śmierć jego obrębem,

Po raz pierwszy Bóg, płacząc, obejmował się z dębem! (PZ 191).

Czytelnika zastanawia to, że obydwaj protagoniści niesamowitej opowieści poddani zostali zabiegowi personifikacji, tj. uczłowieczenia. Grajek w tej fantastycznej historii jest jakby człowiekiem lasu, bytem

\footnotetext{
17 Por. M. P. Markowski, Polska literatura nowoczesna. Leśmian, Schulz, Witkacy, Kraków 2007, s. 131 („egzystencja ludzka jest egzystencją rozdartą, rozpołowioną, między ziemią a niebem").
} 
wywołanym z matecznika dzikiej natury, ze świata pierwotnego, by grać pieśń „od wnętrza zieloną”, czyli pełną życia. To już świat policentryczny, ani teocentryczny, ani antropocentryczny, w którym spotykają się ze sobą siły natury, Bóg, człowiek i byty osobliwe wyobrażone przez poetę lub podmiot jego wiersza. Funkcjonują zatem na równych prawach: dąbczak, czyli grajek niby-człowiek (a więc byt metamorficzny), święci z obrazów, duda i miech (czyli przedmioty), „drzewne obłędy”, leśne troski i śmierci oraz Bóg. Mimo chaosu bytów - można się tu doszukać porządku: podkreśla jego istnienie nie tylko finalna scena pojednania, w której zantropomorfizowany bohater jako kapłan celebruje „wielkie misterium regeneracyjne” ${ }^{18}$, ale również rytm refrenowych powtórzeń, stanowiący o otwartości kompozycyjnej i semantycznej utworu. Świat jest przedstawiony w stanie tworzenia się dzięki magicznemu zaklęciu, o jakże witalnym akcencie:

Grajże, graju, graj,

Dopomoże ci Maj,

Dopomóż ci miech, duda

I wszelka ułuda! (PZ 190-191).

Dąb jest drzewem najszlachetniejszym, najdostojniejszym przedstawicielem Wielkiej Macierzy, może symbolizować człowieka i jego moc niezwykłą, jak też oś świata ułatwiającą komunikację między niebem a ziemią ${ }^{19}$. Dająca się zaobserwować w przywoływanym tekście konwencja ludowej opowieści, pozwala na unaocznienie rzeczywistości przed- czy raczej pozakulturowej, w której zaistnieć może mit człowieka pierwotnego. Pisał o nim Leśmian w eseju Znaczenie pośrednictwa $w$ metafizyce życia zbiorowego, że „był bardziej ludzkim, bardziej sobą, bardziej antropomorficznym" ${ }^{20}$, ale - paradoksalnie - w wielu swoich utworach poetyckich (pomijając późną twórczość z lat trzydziestych) kreował bohatera prymitywnego, który jak Topielec z Łąki pragnął nie odróżniać się od przyrody, stanowić z nią jedność. To z kolei przemawia za ujęciem animistycznym, a więc przeciwstawnym idei antropocentryzmu. Zdaniem Michała Głowińskiego, animizm staje się podstawową zasadą „budowania

\footnotetext{
${ }_{18}$ M. Karwowska, Prapamięć uśpiona. Świat wyobrażeń Bolestawa Leśmiana, Warszawa 2008, s. 109.

19 W. Kopaliński, Stownik..., op. cit., s. 58-59.

${ }^{20}$ B. Leśmian, Znaczenie pośrednictwa $w$ metafizyce życia zbiorowego, [w:] idem, Szkice literackie, oprac. J. Trznadel, Warszawa 2011, s. 23.
} 
jednolitego przedstawienia poetyckiego” w twórczości autora Napoju cienistego ${ }^{21}$.

Tego rodzaju aporię, która różnicuje treści głoszone w wypowiedziach publicystycznych oraz idee zawarte w utworach lirycznych, można tłumaczyć niemożnością pełnego przekładu mowy wiązanej na język dyskursywny. Ponadto, należy pamiętać, że animizm Leśmianowski jest konstruktem ideowym, wysnutym najprawdopodobniej z różnych lektur filozoficznych, popularnych w środowiskach intelektualistów i ludzi sztuki przełomu dziewiętnastego i dwudziestego wieku, a więc z pism Friedricha Nietzschego, Henri Bergsona, Giambattisty Vico, Edwarda Tylora. Animistyczna wizja natury, nie wyklucza antropologicznego i przede wszystkim antropomorficznego wymiaru utworów poetyckich, staje się wręcz jego bazowym elementem.

Sam Leśmian w liście do Przesmyckiego z roku 1911 pisał o tym, że najważniejszą przestrzenią jego twórczości ,jest natura, a więc ziemia”22. To odcięcie się od światów wymyślonych i nadbudówki kultury, będącej wyrazem postępu cywilizacyjnego ludzkości, ale też jej kryzysu, nasuwa pewne skojarzenia z przemyśleniami Friedricha Nietzschego. Niemiecki myśliciel wielokrotnie w swoich dziełach zwracał uwagę na przynależność człowieka do natury i jej wielkie znaczenie dla ludzkiej kondycji. W powrocie do natury widział „nie ruch wstecz, lecz w górę - ku wyżynnej, wolnej, nawet straszliwej naturze i naturalności, takiej, która igra, której wolno igrać wielkimi zadaniami..."23. Tym samym uznawał ów powrót za warunek rozwoju. Stawiał postulat:

Z powrotem przełożyć człowieka na naturę; zapanować nad wieloma próżnymi i marzycielskimi interpretacjami i ubocznymi sensami, jakie dotychczas nagryzmolono i namalowano na tym wieczystym tekście podstawowym homo natura ${ }^{24}$.

${ }^{21}$ M. Głowiński, Zaświat przedstawiony. Szkice o poezji Bolestawa Leśmiana, Warszawa 1981, s. 35.

${ }^{22}$ List nr 81: Do Zenona Przesmyckiego [XII? 1911], [w:] B. Leśmian, Utwory dramatyczne. Listy, oprac. J. Trznadel, Warszawa 2012, s. 373.

${ }^{23}$ F. Nietzsche, Zmierzch bożyszcz, czyli jak filozofuje się mtotem, tłum. i wstęp G. Sowiński, Kraków 2013, s. 132.

24 F. Nietzsche, Poza dobrem i złem. Preludium do filozofii przyszłości, tłum. i wstęp G. Sowiński, Kraków 2012, s. 182. 
Niejednokrotnie przekonywał, że człowiek jest naturą, przynależy do niej, jest zwierzęciem racjonalnym. Krytykował „zaświatowców” i ich odczłowieczony świat, przeciwstawiając mu „ziemską treść” i zdrowe ciało²5.

Wizję ziemskiego życia w objęciach natury, w cielesnym i instynktownym wymiarze, ukazuje poeta w innym „leśnym” wierszu Łąki Pragnieniu:

Chciałbym w lesie, w ostępach dzikiego błędowia,

Mieć chałupę - plecionkę z chrustu i sitowia,

Zawieszoną wysoko w zagłębiach konarów,

Nad otchłanią jam rysich i wężowych jarów.

(...)

I chciałbym przez przygodny wśród gałęzi przezior

Patrzeć, pieszcząc, w noc- $w$ gwiazdy i w błyskania jezior

I za boga brać wszelkie lśniwo u błękitu,

I na piersi dziewczęcej doczekać się światu,

A słońce witać krzykiem i wrzaskiem i wyciem,

Żyć na oślep, nie wiedząc, że to zwie się życiem -

I pewnej nocy przez sen zaśmiać się w twarz niebu (...). (PZ 269).

Życie ziemskie jest w tym wypadku przeciwstawione zarówno egzystencji kartezjańskiej, jak również teologicznemu modelowi świata, z dominującą rolą Absolutu. Wpływy nietzscheanizmu są także tutaj widoczne, szczególnie w wersach traktujących o buncie przeciwko Niebu i animalnym zakorzenieniu człowieka, jak również o instynktownym życiu w ekstazie, wyzbytym racjonalizmu. Warto przypomnieć, że już w dużo wcześniejszej korespondencji z Miriamem (u schyłku okresu kijowskiego) rozwijał Leśmian refleksje o podobnej treści ${ }^{26}$. Jednak w analizowanym wierszu bliżej do panteizmu niż antychrześcijańskiego nastawienia autora Zmierzchu bożyszcz.

\footnotetext{
25 F. Nietzsche, Tako rzecze Zaratustra, tłum. W. Berent, wyd. II, Kraków 2010, s. 32.

${ }^{26}$ List nr 4: Do Zenona Przesmyckiego [Kijów, 1900], [w:] B. Leśmian, Utwory dramatyczne..., op. cit., s. 290. Padają tu następujące sformułowania, niewątpliwie nawiązujące do dzieł Nietzschego: „Przekonałem się, że największym geniuszem człowieka jest to, że ten robak lichy wygrzebał się z błota nicości na słońce”; „czuję w sobie taką siłę i potęgę, że samemu Panu Bogu w twarz bym cisnął te słowa, żem silny”; „Marzenia moje tymczasem, są potężniejsze ode mnie. (...) Zlewam się z nimi powoli jak cień ze światłem, a po każdym takim zlaniu się odczuwam radość i ekstazę".
} 
W wierszach autora Napoju cienistego, w których pojawia się topos lasu, wysuwająca się na pierwszy plan natura może być odczytywana jako „metafora uczasowionej, nieogarnionej a nieprzebytej egzystencji” ${ }^{27}$. Ukazywana w różnorodny sposób, daje asumpt do rozmaitych interpretacji. Zazwyczaj jednak wiąże się bądź to z idealizowaniem lasu jako prapoczątku, który ukrywa najcenniejsze wartości, co podkreśla często stosowany epitet odsyłający do złota ${ }^{28}$, bądź też z ukazywaniem tragicznej kondycji człowieka - odmieńca, próbującego odnaleźć swoje właściwe miejsce w kosmosie. Co prawda, już wierszach Zielonej godziny z Sadu rozstajnego dostrzegamy odsłonięcie idei symbolizmu realistycznego, która wiąże się z poszukiwaniem mediacji między różnymi bytami. Jednak nie dochodzi doń z powodu pozostawania protagonisty opisywanych w poemacie zdarzeń pod wpływami principio individuationis. Dopiero rezygnacja z tej zasady - która dokonuje się w wierszach Dąb i Pragnienie, a także w innych utworach Łąki - ukazuje teatrum lasu jako miejsce pojednania wspomnianych bytów.

Ukazane $\mathrm{w}$ nich stany zatopienia $\mathrm{w}$ instynktownym byciu nie wywołują refleksji o konflikcie $\mathrm{z}$ innymi. Podmiot liryczny wiersza Pragnienie marzy o domu, ale jakże różnym od wyobrażeń ludzi wychowanych w cywilizacji zurbanizowanej, chce „mieć chałupę - „plecionkę z chrustu i sitowia, / zawieszoną wysoko w zagłębiach konarów” (PZ 269). Chce w pełni oddać się pędowi życia. Wydaje się, że taka kreacja bohatera wiąże się z przemianą światopoglądu Leśmiana, który głęboko przemyślał koncepcje Bergsona i odsunął na bok indywidualistyczne postrzeganie człowieka, inspirowane Zaratustrą Nietzschego, tj. koncepcją nadczłowieka i woli mocy. Z autorem Niewczesnych rozważań może łączyć te przedstawienia jedynie dionizyjska wizja życia i detronizacja Boga jako Absolutu.

Postawa bohatera lirycznego (a także jego doświadczenia i stany uczuciowe) w wierszach Leśmiana daje się identyfikować ze stanowiskiem poety. Jeden i drugi, stawiają sobie za cel poznanie prawdy o życiu oraz tworzenie nowych faktów tego życia. Istotą świata staje się wymienność i metamorficzność rzeczywistości: kreowanej i istniejącej. Słowo jest przesłanką trwania bytu, a działania poety i „śpiewaka” (czyli ja lirycznego wierszy) polegają na spokrewnianiu i utożsamianiu słowa oraz jego

\footnotetext{
27 Ibidem, S. 116.

${ }^{28}$ Złoto może symbolizować trudny do odnalezienia skarb, dobra duchowe lub oświecenie najwyższego rzędu. Zob.: J. E. Cirlot, Stownik symboli, tłum. I. Kania, Kraków 2007, s. 477.
} 
pozasłownego bytu29. Przyroda i wiersz zawierają w sobie tajemnicę powtarzalności, tajemnicę rytmu. O tej podległości rytmowi, zarówno sztuki, jak i życia pisał przekonująco Leśmian m.in. w jednym ze szkiców literackich:

Zaznaczymy tu tylko mimochodem, że wszelkiemu procesowi istnienia towarzyszy ruch rytmiczny. Łatwo to sprawdzić na obiegu krwi, na biciu serca, na ruchach gwiazd i planet. Nawet $\mathrm{w}$ wykonaniu zwykłej pracy koniecznej do dźwigania ciężarów, do przesuwania ich z miejsca na miejsce pomagamy sobie nieświadomie i mimo woli piosenką solową lub chóralną, która nam ułatwia wprawienie ciała lub kilku ciał w ruch rytmiczny, aby go uzgodnić i przelać na martwy ciężar.

Praca twórcza jest tak samo i przede wszystkim pracą rytmiczną. Ujawnia ona swój rytm w utworach, z tego właśnie rytmu bezpośrednio powstałych. Piękno tych utworów między innymi polega i na tym, że swą budową stwierdzają śpiewne źródło swych narodzin - że przejrzyścieją całkowicie niematerialną istotą rytmu, który był ich pobudką twórczą i który towarzyszył ich wcieleniu. Słowa idą w ślad za rytmem przewodnim jak za nicią Ariadny3o.

W teatrum lasu, które odnajdujemy w liryce Leśmiana, z reguły umieszcza on jednak nie artystę, lecz człowieka w ogóle, człowieka jako rzecz samą w sobie. Prawie wcale nie odnosi się on do kwestii sztuki i działań artystycznych ${ }^{31}$. Wyjątkiem jest wiersz rosyjski Piesnia pro siebia (Pieśń o sobie), z wczesnego okresu twórczości, w którym mówi o pieśni ukrytej w sercu poety, wciąż ponawianej, głoszącej po wielokroć: nowy płacz i nowy śmiech ${ }^{32}$. Tutaj podmiot liryczny (autor) porównuje do lasu swoją sferę wewnętrzną i najbardziej osobistą, to co najistotniejsze i najcenniejsze dla twórcy. Powraca do tej idei w jednym z późnych utworów Napoju cienistego, który opatrzył tytułem $W$ lesie. Tu w metaforycznej gęstwinie życia podmiot układa myśli-sny, „co niosą w blask - zmarłe pustkowie” (PZ 408). Tu wśród pni czasów minionych rozsłonecznia swój świat prawie we franciszkańskim nastroju:

\footnotetext{
${ }^{29}$ K. Dybciak, „Ogród oderwany od przyczyny” - Bolestaw Leśmian, [w:] Poeci dwudziestolecia międzywojennego, red. I. Maciejewska, Warszawa 1982, s. 480.

${ }^{30}$ B. Leśmian, Z rozmyślań o poezji, [w:] idem, Szkice literackie..., op. cit., s. 66.

${ }^{31}$ Mam tu na uwadze bezpośrednie odwołania do zagadnień twórczości artystycznej. Natomiast nie ulega wątpliwości, że projekty i wizje relacji człowiek - natura - Bóg, zawarte $\mathrm{w}$ analizowanych w niniejszym szkicu wierszach, można również interpretować w odniesieniu do poglądów ich autora na sztukęi literaturę.

$3^{2}$ Zob. tekst oryginalny w języku rosyjskim (PZ 641) oraz polski w tłumaczeniu Jacka Trznadla (PZ 653).
} 
I właśnie, sycąc cienistą snu smużkę

Wspomnianą nagle z lat dawnych doliną,

Spożywam chleba wonnego całuszkę

Razem ze słońca na niej odrobiną... (PZ 408).

Natomiast w pośmiertnie ogłoszonym tekście o incipicie „Niegdyś dom mój ochoczy i świat za dąbrową” las jawi się jako coś bardzo istotnego i osobistego, prapoczątek, ale też jako raj świadomie czy półświadomie porzucony. Mamy tu także zarysowaną ideę transgresji w wymiarze jednostkowym.

Jednak w większości wierszy, odwołujących się do topiki leśnej, poeta układa pieśń nie tylko o sobie. Kreowany przez niego świat wykracza poza współczesność, w ogóle poza ramy czasowe i przestrzeń prywatnych uczuć. To także pieśń o różnych niezhierarchizowanych bytach i nicości: o człowieku obdarzonym tożsamością metamorficzną33, naturze, Bogu i pozaludzkich dziełach. Wiedza o nich zdaje się być dostępna jedynie na drodze niezwykłych doznań, ekstaz i olśnień.

\section{Literatura/References}

\section{Źródła}

Leśmian B., Poezje zebrane, oprac. J. Trznadel, Warszawa 2010.

Leśmian B., Szkice literackie, oprac. J. Trznadel, Warszawa 2011.

Leśmian B., Utwory dramatyczne. Listy, oprac. J. Trznadel, Warszawa 2012.

\section{Opracowania}

Boniecki E., Archaiczny świat Bolesława Leśmiana. Studium historycznoliterackie, Gdańsk 2008.

Cirlot J.E., Stownik symboli, tłum. I. Kania, Kraków 2007.

Dybciak K., „Ogród oderwany od przyczyny” - Bolestaw Leśmian, [w:] Poeci dwudziestolecia międzywojennego, t. 1, red. I. Maciejewska, Warszawa 1982, s. 477-517.

Głowiński M., Zaświat przedstawiony. Szkice o poezji Bolestawa Leśmiana, Warszawa 1981.

Jachimowicz M., Bolesna stawa Leśnego Miana, „Poezja” 1967, nr 12, s. 71-72.

Karwowska M., Prapamięć uśpiona. Świat wyobrażeń Bolesława Leśmiana, Warszawa 2008.

33 Zob. D. Wojda, Tropy Nietzschego i tropy Leśmiana: między różnica a tożsamościa metamorficzna, [w:] Leśmian nowoczesny i ponowoczesny, red. B. Grodzki, D. Trześniowski, Radom 2012, s. 330, 332. 
Karwowska M., Wątki antropologiczne $w$ «Sadzie rozstajnym» Bolestawa Leśmiana, [w:] Stulecie «Sadu rozstajnego», red. U.M. Pilch, M. Stala, Kraków 2014, s. 320-340.

Kopaliński W., Stownik symboli, Warszawa 2001.

Łopuszański P., „Idq̨cy z prawdq u warg i u powiek...”. Próba nowego spojrzenia na twórczość Bolestawa Leśmiana, „Teksty Drugie” 2002, nr 6, s. 180-195.

Markowski M.P., Polska literatura nowoczesna. Leśmian, Schulz, Witkacy, Kraków 2007.

Nietzsche F., Poza dobrem i złem. Preludium do filozofii przyszlości, tłum. i wstęp G. Sowiński, Kraków 2012.

Nietzsche F., Zmierzch bożyszcz, czyli jak filozofuje się młotem, tłum. i wstęp G. Sowiński, Kraków 2013.

Nietzsche F., Tako rzecze Zaratustra, tłum. Wacław Berent, wyd. II, Kraków 2010.

Podraza-Kwiatkowska M., Z rozważań nad tytutem «Sad rozstajny», [w:] Stulecie «Sadu rozstajnego», red. U. Pilch, M. Stala, Kraków 2014, s. 7-20.

Rossa A., Impresjonistyczny świat wyobraźni. Poetycka i malarska kreacja pejzażu. Studium wybranych motywów, Kraków 2003.

Sandauer A., Pośmiertny tryumf Młodej Polski (Rzecz o Bolestawie Leśmianie), [w:] idem, Poeci trzech pokoleń, wyd. 4. rozszerzone, Warszawa 1973, s. 5-35.

Wojda D., Tropy Nietzschego i tropy Leśmiana: między różnica a tożsamościa metamorficzna, [w:] Leśmian nowoczesny i ponowoczesny, red. B. Grodzki, D. Trześniowski, Radom 2012, s. 309-332. 